\title{
Justyna Rudnicka
}

\section{Więcej niż tło. Muzyka Pawła Mykietyna w teatrze Krzysztofa Warlikowskiego'}

\section{Abstract}

\section{More Than Just a Background: The Music of Paweł Mykietyn in} Krzysztof Warlikowski's Theatre

The article is devoted to the role and functions of Paweł Mykietyn's music in the theatre of Krzysztof Warlikowski. The modified version of music classification in the theatre proposed by Patrice Pavis serves as a starting point for the considerations. Providing the examples of certain performances, I describe each function as well as the characteristics of Paweł Mykietyn's theatrical music. It turns out that in the case of Warlikowski's theatre one cannot see music as an addition - music is an inseparable element in the process of establishing the meanings in each staging.

\section{Keywords}

\section{theatrical music, Krzysztof Warlikowski, Paweł Mykietyn}

1 Artykuł jest fragmentem pracy magisterskiej napisanej pod kierunkiem prof. Macieja Gołąba i obronionej w Instytucie Muzykologii Uniwersytetu Wrocławskiego W 2018 roku. 
Muzyka w teatrze traci swoją samodzielność. Wplątana zostaje w sieć tworzyw, z których każde wywodzi się z innej dziedziny sztuki i rządzi się odrębnymi prawami. $Z$ tego powodu nie można muzyki teatralnej badać w izolacji od innych elementów dzieła. $Z$ drugiej strony semiotyczny ładunek, w jaki wyposażona jest muzyka w teatrze, sprawia, że możemy mówić o konkretnych funkcjach, które dany fragment muzyczny pełni w procesie konstruowania narracji scenicznej. Klasyfikacje owych funkcji są różne i przyjmują zarówno opisowy, jak i normatywny charakter.

I tak Tadeusz Szulc w artykule Muzyka i teatr ${ }^{2}$ pisze o dwóch możliwościach istnienia muzyki w teatrze - jako rekwizytu teatralnego oraz imitacji. Pierwsza z nich miałaby polegać na włączeniu muzyki w obręb inscenizacji jako pewnego obiektu, na podobieństwo elementów scenografii. Źródło dźwięku (autor ma na myśli żywych instrumentalistów) powinno być widoczne i przystawać do sytuacji scenicznej. Druga możliwość to muzyczne naśladowanie pewnych odgłosów o niemuzycznej proweniencji, wykorzystywane przede wszystkim dla celów komicznych. Witold Wroński tworzy natomiast rodzaj kodeksu włączania muzyki w dzieło teatralne ${ }^{3}$. Pierwszy z sześciu wymienionych przez niego punktów określa funkcję muzyki jako tożsamą z funkcją sztuk wizualnych, takich jak dekoracja, światło, kostiumy. Za pozytywny uważa aspekt potęgowania wrażeń i tworzenia nastroju, który jednak nie może przeciwstawiać się słowu - muzyka ma łączyć się z tekstem literackim oraz ułatwiać widzowi poznanie go ${ }^{4}$. Małgorzata Komorowska w tekście Muzyka w teatrze dramatycznym ${ }^{5}$ - prócz funkcji podobnych do już wymienionych - zwraca uwagę na to, że muzyka w pewien sposób komentuje warstwę sceniczną, a także akcentuje najważniejsze kwestie przedstawione na scenie. Muzyka bywa, według

2 Zob. T. Szulc, Muzyka i teatr, w: Wprowadzenie do nauki o teatrze, t. 2, O tworzywie i twórcach dzieła teatralnego, red. J. Degler, Wydawnictwa Uniwersytetu Wrocławskiego, Wrocław 1976, s. 535.

3 Zob. W. Wroński, Muzyka w dramacie, tragedii i komedii, w: Wprowadzenie do nauki..., t. 2, dz. cyt., s. 540 .

4 Wymienione zasady ewokują pytania m.in. o to, jak w praktyczny sposób muzyka ma pomagać odbiorcy w zrozumieniu tekstu oraz co oznacza, że nie powinna mu „przeszkadzać”. Warto jednak zauważyć, że w czasie powstania omawianego tekstu powszechnie funkcjonowała tzw. literacka teoria dramatu, wedle której teatr ma za zadanie uobecnić dramat na scenie i nie stanowi odrębnego dzieła.

5 Zob. M. Komorowska, Muzyka $w$ teatrze dramatycznym, w: Wprowadzenie do nauki..., t. 2, dz. cyt., s. 541-546. 
Komorowskiej, również „kurtyną, kondensatorem czasu teatralnego, spoiwem materii literackiej, przerywnikiem, ornamentem, elementem humoru, aktorem, maluje wraz ze scenografią tło obyczajowe, narodowe, historyczne, potęguje napięcie dramatyczne" 6 . Funkcję ilustratywną, rozumianą jako wzmocnienie nastroju poszczególnych scen, uważa autorka za wygasającą $\mathrm{w}$ teatrze, rozwijającą się za to w sztuce filmowej ${ }^{7}$.

Muzyka bywa również porównywana do scenografii - Jacques Copeau uważa, że „stwarzając frazę i łącząc z nią gest, tworzy również ruch, odmierza rytm kroków [...], stwarza zasadniczą dekorację"8. $\mathrm{Na}$ jej funkcję zwracają również uwagę semiolodzy - Tadeusz Kowzan $\mathrm{w}$ artykule Znak $w$ teatrze ${ }^{9}$ wymienia trzynaście znaków teatralnych. Wśród nich znajduje się również muzyka, która może istnieć przede wszystkim jako rodzaj ilustracji sugerującej stan emocjonalny bohaterów. Poszczególne frazy stają się wedle Kowzana „znakiem niepokoju, smutku, pośpiechu, radości, rzewności"10. Dodatkowo ma za zadanie przybliżyć odbiorcy atmosferę danego miejsca akcji lub jej czasu historycznego. Również w doborze instrumentów autor dopatruje się pewnego rodzaju kodu wspólnego dla kompozytora i odbiorców. Osobnym znakiem u Kowzana jest „efekt dźwiękowy”, rozumiany jako sfera dźwięków intencjonalnych, wyłączający zatem ze swego obszaru wszelkie „znaki naturalne”, wśród których Kowzan wymienia m.in. skrzypienie drzwi czy odgłos kroków. Efekty dźwiękowe mogą być więc dla odbiorcy znakiem pory dnia, miejsca, pogody i innych okoliczności. W świetle teorii informacji muzyka jest natomiast jednym $\mathrm{z}$ subkodów - jednolitych pod względem ekspresji znakowych podsystemów, które jednak mogą się ze sobą łączyć, zyskując synkretyczny charakter. Subkod zwany muzyką nie jest jednak przez badaczy wiązany z subkodami innymi niż słowo - jako przykład synkretyzmu podany zostaje śpiew, łączący w sobie warstwę muzyczną i tekstową ${ }^{11}$.

6 Tamże, s. 544.

7 Tamże, s. 545.

8 Zob. J. Copeau, Naga scena, tłum. M. Skibniewska, Wydawnictwa Artystyczne i Filmowe, Warszawa 1972, s. 58.

9 Zob. T. Kowzan, Znak w teatrze, „Dialog” 1969, nr 3, s. 88-104.

10 Tamże, s. 97.

11 Zob. E. Balcerzan, Z. Osiński, Spektakl teatralny w świetle teorii informacji, w: Wprowadzenie do nauki o teatrze, t. 1, Dramat, teatr, red. J. Degler, Uniwersytet Wrocławski im. Bolesława Bieruta, Wrocław 1974. 
Nieco szersze spojrzenie na muzykę $\mathrm{w}$ teatrze dramatycznym prezentuje Andrzej Hausbrandt ${ }^{12}$. Podkreśla przede wszystkim jej rolę w odnoszeniu się wprost do emocji odbiorcy, w tworzeniu scenicznego nastroju z pominięciem sfery intelektu, zarezerwowanej dla słowa. Przypisuje muzyce funkcję formotwórczą, jako elementowi wyznaczającemu rytm spektaklu bądź poszczególnych jego scen. Zauważa również możliwość kontrapunktowego zastosowania muzyki, tworzącego rodzaj „efektu obcości” wraz z wypowiadanym tekstem bądź gestem.

Przywołane (wszak już nienowe) próby opisu miejsca i funkcji muzyki w spektaklu teatralnym charakteryzuje zazwyczaj myślenie o służebnej roli wobec innych elementów przedstawienia ${ }^{13}$. Pomiędzy wypowiadanym tekstem, gestem aktora itp. a muzyką rzadko zauważa się wzajemny wpływ, istnieje jedynie działanie jednostronne - na zasadzie „ornamentu” muzyka ma służyć wzmocnieniu innych komponentów dzieła. Nie jest traktowana jako element konieczny dla zaistnienia teatru, przypisuje się jej miejsce podrzędne. Dodatkowo większość przywołanych klasyfikacji zdaje się utożsamiać warstwę muzyczną w teatrze $\mathrm{z}$ wyjątkowo prostymi i czytelnymi przykładami muzycznymi. Teoretycy nie biorą również pod uwagę współczesnych technik kompozytorskich. Zdaje się, że w przypadku teatru Krzysztofa Warlikowskiego ${ }^{14}$ taki sposób myślenia jest dużym uproszczeniem. Wynika to zarówno ze sposobu pracy nad spektaklem, w którą od początku angażowany jest cały zespół - również kompozytor - jak i specyfiki samej muzyki Pawła Mykietyna, o której reżyser mówi, że „wchodzi w kości” ${ }^{15}$, a więc bardzo bezpośrednio i na trwałe „infekuje" odbiorcę pewnym nastrojem, dalekim od pospolitego podziału na smutek czy radość.

12 Zob. A. Hausbrandt, Elementy wiedzy o teatrze, Wydawnictwa Szkolne i Pedagogiczne, Warszawa 1981, s. 133-137.

13 Należy zaznaczyć, że współczesna teatrologia odchodzi od silnego hierarchizowania i oddzielania poszczególnych komponentów tworzących spektakl. Jak pisze Patrice Pavis, „odkrywa się muzyczność tekstu i teatralność muzyki”. Zob. P. Pavis, Słownik terminów teatralnych, tłum. S. Świontek, Zakład Narodowy im. Ossolińskich, Wrocław 1998, s. 314.

14 Teatr Krzysztofa Warlikowskiego utożsamiam ze stałym zespołem twórców skupionych wokół reżysera Krzysztofa Warlikowskiego. Ważną postacią jest w tym wypadku Paweł Mykietyn, który skomponował muzykę niemal do wszystkich przedstawień reżysera.

15 Zob. K. Warlikowski, Muzyka, która wchodzi w kości, rozmowę przepr. P. Dobrowolski, „Notatnik Teatralny” 72-73 (2013), s. 39. 
W niniejszym artykule, odwołując się do konkretnych spektakli, staram się opisać funkcje oraz specyfikę muzyki w teatrze Krzysztofa Warlikowskiego. Nie jest to zadanie proste ze względu na silne zespolenie zjawisk muzycznych z innymi komponentami widowiska teatralnego. Właściwie niemożliwe jest również sprowadzenie roli muzyki w danej scenie czy całym przedstawieniu do jednej, jasno określonej funkcji. $\mathrm{Z}$ tego powodu poniższą klasyfikację należy traktować jako jeden $\mathrm{z}$ wielu możliwych (choć zawsze niepełnych) sposobów uporządkowania. Poszczególne funkcje, do których się odwołuję, są nieco skróconym katalogiem autorstwa Patrice’a Pavisa ${ }^{16}$.

\section{Funkcja ilustracyjna}

Wbrew nazwie tej funkcji, która mogłaby sugerować wtórność muzyki wobec działań scenicznych, bardzo rzadko mamy w teatrze Warlikowskiego do czynienia $\mathrm{z}$ muzyką, która naśladuje to, co widzimy na scenie. Zdaje się, że trafniejszym określeniem byłoby tu „komentowanie" z zaznaczeniem, że często muzyka może na zasadzie kontrapunktu stać się „,ironicznym komentarzem” wobec wypowiadanego tekstu, gestyki aktorów, scenografii ${ }^{17}$.

Tak dzieje się chociażby w Poskromieniu złośnicy ${ }^{18}$. Pierwsze tematy muzyczne towarzyszące części Przygotowanie oplatają typowo humorystyczne sceny aurą niepokoju, grozy, niepewności. Szykowanie komedii, w której tytułową rolę ma zagrać pijak Okpisz, przekonany, że jest bogatym władcą, bynajmniej nie jest zabawne. Zdaje się, że

16 W haśle Muzyka sceniczna Pavis wymienia następujące funkcje, jakie muzyka pełni w teatrze: funkcja ilustracyjna, funkcja scalająca niezsynchronizowane składniki przedstawienia, funkcja kontrapunktowa, funkcja sygnalizacyjna, filmograficzne zastosowanie muzyki. Zob. P. Pavis, dz. cyt., s. 315.

17 Por. tamże.

18 Poskromienie złośnicy na podstawie dramatu Williama Shakespeare’a w przekładzie Stanisława Barańczaka. Reżyseria: Krzysztof Warlikowski, scenografia: Małgorzata Szczęśniak, muzyka: Paweł Mykietyn; prapremiera w Teatrze Dramatycznym m.st. Warszawy 3 stycznia 1998 roku. Wystąpili: Danuta Stenka, Małgorzata Kożuchowska, Adam Ferency, Marcin Troński, Marcin Dorociński, Paweł Tucholski, Andrzej Szeremeta. Prócz aktorów na scenie pojawili się również muzycy: Klaudiusz Baran, Piotr Widlarz, Fabian Włodarek, Mirosław Mozoł (akordeony); Karol Gołowacz, Aleksander Laskowski, Alina Mleczko, Karol Soroka, Alicja Wołyńczuk (saksofony). 
odbiorca bardziej ufa muzyce - to ona, mająca siłę bezpośredniego wpływu na słuchacza, nie pozwala się śmiać nawet podczas niemal kabaretowej sceny pogoni Okpisza za służącym w damskim stroju. Muzyka w tej scenie ma funkcję nie tyle „podkreślającą i potęgującą nastrój" ${ }^{19}$, ile ten nastrój stwarzającą. Podobnie rzecz ma się w scenie miłosnych pieszczot Lucencja i Bianki, komentowanych przez akordy o dysonansowych współbrzmieniach, niedoczekujących się rozwiązania. Tworzą one atmosferę zawieszenia, niepewności, napięcia, ale i pewnej inercji wynikającej z wolnego tempa i nieśpiesznych zmian. W Burzy ${ }^{20}$ nastrój pierwszych scen (rozmowa Prospera z Mirandą oraz Arielem) budowany jest przez krótkie motywy o jasnej barwie oraz niski głos burdonowy. Wraz z rozwojem akcji burdon ten zaczyna na zasadzie powolnego glissanda zmieniać wysokość dźwięku na wyższą, a strój równomiernie temperowany zostaje wzbogacony o mikrotony. Wrażenie płynności, jakie się w ten sposób wytwarza, nadaje całej scenie wyjątkowo oniryczny charakter (co znowu współgra z warstwą sceniczną - stołem oświetlonym kilkoma świecami, spokojną opowieścią Prospera, snem Mirandy).

Z podobnym muzycznym komentarzem mamy do czynienia w Oczyszczonych ${ }^{21}$. W tym spektaklu klastery tworzone za pomocą syntezatorowych brzmień rzeczywiście potęgują nastrój grozy i niepokoju obecny już w scenach, którym towarzyszą. Prócz nich pojawiają się również piosenki, które pomiędzy niektórymi scenami śpiewa na żywo Renate Jett. Status jej postaci nie jest do końca określony. Znajduje się ona niejako poza fikcją teatralną, co pokazuje sławetny monolog

19 Zob. P. Pavis, dz. cyt., s. 315.

20 Burza na podstawie dramatu Williama Shakespeare’a w przekładzie Stanisława Barańczaka. Reżyseria: Krzysztof Warlikowski, scenografia: Małgorzata Szczęśniak, muzyka: Paweł Mykietyn; premiera 4 kwietnia 2003 w Teatrze Rozmaitości Warszawa. Wystąpili: Zygmunt Malanowicz, Marek Kalita, Adam Ferency, Andrzej Chyra, Redbad Klynstra, Lech Łotocki, Renate Jett, Stanisława Celińska, Jacek Poniedziałek, Małgorzata Hajewska-Krzysztofik, Magdalena Cielecka, Marianna Orłoś, Teresa Owczynnikow, Maria Świerszcz, Fabian Włodarek.

21 Oczyszczeni na podstawie dramatu Sarah Kane w przekładzie Krzysztofa Warlikowskiego i Jacka Poniedziałka. Reżyseria: Krzysztof Warlikowski, scenografia: Małgorzata Szczęśniak, muzyka: Paweł Mykietyn, śpiew: Renate Jett, reżyseria świateł: Felice Ross; prapremiera we Wrocławskim Teatrze Współczesnym 15 grudnia 2001. Wystąpili: Stanisława Celińska, Małgorzata Hajewska-Krzysztofik, Mariusz Bonaszewski, Redbad Klynstra, Jacek Poniedziałek, Thomas Schweiberer, Tomasz Tyndyk, Renate Jett. 
o miłości22 ${ }^{22}$ w którym burząc czwartą ścianę, zwraca się wprost do widza, czyniąc go niejako powiernikiem intymnych i wstydliwych wyznań. Jej zewnętrzna wobec akcji scenicznej rola (w której można doszukać się funkcji chóru w tragedii antycznej) objawia się również we wspomnianych piosenkach. Są to krótkie utwory muzyczne, w których angielski tekst (zaczerpnięty z Sarah Kane - tym razem z dramatu 4.48 Psychosis) podawany jest za pomocą melorecytacji na jednej wysokości dźwięku (pierwsza piosenka) lub z niewielkimi zmianami interwałowymi (druga i trzecia piosenka). Towarzyszy im tworzony przez syntezator akompaniament, o gęstej fakturze plam dźwiękowych.

Za pewien rodzaj ilustracyjności, który jest chyba najbliższy rozumieniu tego terminu przez Pavisa, można uznać tzw. dekorację dźwiękową, definiowaną przez tego samego autora jako „sposób sugerowania za pomocą efektów dźwiękowych istnienia strefy gry poza sceną"23. Jest ona zatem „normalnym środkiem stwarzania iluzji przestrzeni, w której toczy się akcja słuchowisk radiowych" 24 . Z muzykologicznego punktu widzenia możemy (za Pierre’em Schaefferem) nazwać ją muzyką akuzmatyczną, czyli rodzajem muzyki elektroakustycznej, która jest oderwana od własnego źródła dźwięku ${ }^{25}$. W spektaklu nie jest ona jednak samodzielna, a i cel jej zastosowania różni się od Schaefferowskiego postulatu oddania się ,wyłącznie i w całości słuchaniu, by odkryć instynktownie ścieżki prowadzące do tego, co czysto "dźwiękowe»"26. Pełni tu raczej funkcję ilustracji właśnie, pewnego tła, które niekiedy przejmuje rolę scenografii, dookreślając miejsce akcji, oraz stwarza pejzaż dźwiękowy dla wypowiadanego tekstu. Dekoracją dźwiękową są chociażby odgłosy samolotu (uwspółcześniając ostatni dramat Shakespearea, Warlikowski zamienia tradycyjny okręt na samolot), które zapełniają nieoświetloną przestrzeń już w pierwszej scenie Burzy. Również opowieść Prospera o wyrzuceniu jego i Mirandy $\mathrm{z}$ księstwa Mediolanu dopełniają słyszane z oddali ludzkie okrzyki i agresywne skandowanie. Wyjątkowo ilustracyjny jest również odgłos

22 Tekst monologu Warlikowski zaczerpnął z dramatu Łaknąć Sarah Kane.

23 Zob. P. Pavis, dz. cyt., s. 94.

24 Tamże.

25 Zob. P. Schaeffer, Akuzmatyka, tłum. J. Kutyła, w: Kultura dźwięku. Teksty o muzyce nowoczesnej, red. Ch. Cox i D. Warner, słowo/obraz terytoria, Gdańsk 2010, s. $106-113$.

26 Tamże, s. 113. 
bicia dzwonów pojawiający się wraz z monologiem Ariela ${ }^{27}$, w którym mowa właśnie o biciu w dzwony.

W Oczyszczonych dekorację dźwiękową możemy odnaleźć w odgłosach dzieci bawiących się na dworze. Zostaje ona użyta jako tło w scenie śmierci Grahama oraz miłosnego wyznania (zaślubin) Roda i Carla. Jej funkcję można potraktować wielorako. Z pewnością zastępuje scenografię, sugerując odbiorcy, że rzecz dzieje się na zewnątrz, w jakiejś przestrzeni publicznej. Co ciekawe, możemy odnaleźć tu silną korelację z dramatem, którego tekst poboczny wskazuje, że w scenie wymiany obrączek przez Roda i Carla „dochodzą dźwięki meczu krykieta rozgrywającego się po drugiej stronie ogrodzenia" ${ }^{28}$. Patrząc jednak przez pryzmat całego spektaklu, ten rodzaj dekoracji dźwiękowej wiąże się z bezpieczeństwem i otwarciem. Głucha cisza, w której później wybrzmiewa głos i ciało, znamionuje już zamknięcie i niemożność wyjścia z dziwnego szpitala, w którym panuje doktor-psychopata.

\section{Funkcja porządkująca}

Funkcja porządkująca polega na łączeniu ze sobą różnych składników oraz poszczególnych części przedstawienia. Może mieć zatem charakter wertykalny (gdy staje się spoiwem dla elementów pojawiających się jednocześnie - na przykład dla słowa i ruchu) oraz horyzontalny (gdy łączy poszczególne sceny, akty i inne jednostki następujące po sobie).

Drugi przypadek reprezentuje muzyka w Poskromieniu złośnicy. Jeśli za sygnał podziału poszczególnych jednostek przedstawienia przyjmiemy tzw. blackout (ściemnienie lub zgaszenie świateł), to muzyka towarzyszy niemal każdemu przejściu z jednej sceny w kolejną. Saksofonowy temat pojawia się po ostatniej scenie z Przygotowania, łącząc dwie odrębne rzeczywistości - dwór oraz sztukę teatralną, jednocześnie (bez użycia kurtyny) zasklepiając teatralne „szwy”, takie jak zmiana dekoracji czy wejście na scenę nowych postaci.

Muzyka występująca pomiędzy poszczególnymi częściami przedstawienia ma bardzo długą tradycję, objawiającą się chociażby w intermezzach (renesansowych widowiskach teatralno-muzycznych) czy w mu-

27 W tej roli wystąpiła Magdalena Cielecka.

28 Zob. S. Kane, Oczyszczeni, tłum. A. Kaszowska, [b.m., b.r.], https://docer.pl/doc/10se8 [dostęp: 14.10.2019], s. 3 . 
zyce antraktowej (występującej pomiędzy aktami, często stylistycznie niedopasowanej do treści dzieła). Czy muzykę w Poskromieniu złośnicy można nazwać antraktową? Do pewnego stopnia - jak najbardziej. Pełni bowiem funkcję łącznika pomiędzy poszczególnymi częściami przedstawienia, zapowiadając jednocześnie charakter czy nastrój tego, co ma po niej nastąpić. $Z$ drugiej strony Warlikowski po raz kolejny gra tutaj z tradycją. Muzyka bowiem nie pozostaje na zewnątrz fikcji teatralnej, ale wdziera się w akcję, bardzo szybko zagospodarowując dla siebie przestrzeń sceniczną. W jednej ze scen to muzycy stają się aktorami, wykonując utwór o silnie zaznaczonym rozpoczęciu i zakończeniu, który przez odbiorców potraktowany zostaje jako rodzaj minikoncertu domagającego się oklasków. Warlikowski w ten sposób rozszerza funkcję muzyki, pozwala jej wybrzmieć jako elementowi samodzielnemu, a nie wyłącznie wspierającemu to, co w tradycyjnym myśleniu o teatrze jest najważniejsze, czyli słowo i sztukę aktorską. $\mathrm{W}$ takim traktowaniu warstwy muzycznej zauważalna jest podstawowa właściwość tzw. teatru postdramatycznego, mianowicie odrzucenie hierarchiczności teatralnych środków ${ }^{29}$. Również w duchu tego nurtu Warlikowski nie tyle spaja w jedno różne komponenty, ile daje każdemu z nich przestrzeń i czas na zagranie głównej roli.

Wyjątkowo szczodrze oddaje Warlikowski czas i przestrzeń muzyce w (A)pollonii ${ }^{30}$. Piosenki, które pomiędzy scenami wykonuje Renate Jett z zespołem, nie są wyłącznie krótkim, znaczącym sygnałem. Wyśpiewywane są wszystkie zwrotki (szczególnie zauważalne jest to przy utworze To ostatnia niedziela, który, gdyby miał być tylko znakiem, mógłby zakończyć się na refrenie), a zespół ma na scenie własne miejsce z przygotowanym nagłośnieniem i instrumentami. Piosenki oczywiście pełnią również funkcje muzycznych przerywników-komentarzy, dzielą bowiem strukturę przedstawienia równolegle

29 Zob. H.T. Lehmann, Teatr postdramatyczny, tłum. D. Sajewska, M. Sugiera, Księgarnia Akademicka, Kraków 2004, s. 132-133.

30 (A)pollonia, reżyseria: Krzysztof Warlikowski, adaptacja: Krzysztof Warlikowski, Piotr Gruszczyński, Jacek Poniedziałek, scenografia i kostiumy: Małgorzata Szczęśniak, muzyka: Paweł Mykietyn, Renate Jett, Piotr Maślanka, Paweł Stankiewicz; Premiera w Nowym Teatrze w Warszawie 16 maja 2009. Wystąpili: Magdalena Cielecka, Ewa Dałkowska, Renate Jett, Małgorzata HajewskaKrzysztofik, Maja Ostaszewska, Magdalena Popławska, Andrzej Chyra, Wojciech Kalarus, Marek Kalita, Zygmunt Malanowicz, Adam Nawojczyk, Jacek Poniedziałek, Maciej Stuhr, Tomasz Tyndyk. 
z podziałem tekstowym i scenicznym. Pozwalają odejść poprzedzającej je opowieści oraz zaistnieć opowieści kolejnej. Często towarzyszą również aktorskiemu wyjściu z jednej roli i przeistoczeniu się w kolejnego bohatera. Gdyby wspomóc się przy analizie tego elementu etapami rytuału przejścia wyróżnionymi przez Arnolda van Gennepa ${ }^{31}$, można by powiedzieć, że fazę przejściową (marginalną) wspomaga właśnie muzyka. Tak dzieje się m.in. podczas ostatniej sceny, w której zespół wraz z wokalistką wykonuje piosenkę Pain. Do szklanego pomieszczenia, w którym grają, po kolei schodzą się aktorzy - siadają, kładą się na podłodze, swobodnie opierają się o przezroczyste ściany. Nie są to już postaci teatralne, ale aktorzy właśnie, których wreszcie łączy wspólna, niewielka przestrzeń - zarówno dźwiękowa, jak i fizyczna. Czas trwania piosenki jest czasem dla nich, pewnym buforem, stanem przejściowym pomiędzy postacią a aktorem, przeżyciem indywidualnym a zbiorowym.

\section{Funkcja sygnalizacyjna}

Sygnalizacyjna funkcja muzyki w najprostszy sposób objawia się w stosowaniu motywów przewodnich zapowiadających pojawienie się danej postaci, rekwizytu czy działania. Zdaje się, że funkcja ta najlepiej pokrywa się z rozumieniem muzyki w teorii semiologii teatru i klasyfikacją Tadeusza Kowzana ${ }^{32}$.

Elementy techniki motywów przewodnich stosuje Mykietyn w Burzy. Nie jest to jednak motyw rozumiany jako „struktura powstająca w wyniku współdziałania elementów muzycznych (głównie meliki, rytmiki, harmoniki)" ${ }^{33}$, raczej jako pewien sygnał, który nie sprowadza się do melodii czy rytmu, ale na przykład konkretnego instrumentu, charakterystycznych odgłosów czy rodzaju brzmienia.

31 Wedle Gennepa w fazie przejściowej jednostka jest pozbawiona statusu - wyszła już z poprzedniego stanu, ale jeszcze nie znalazła się w tym, do którego dąży. W omawianym kontekście byłby to dla aktorów czas tzw. „wychodzenia z postaci”. Zob. A. van Gennep, Obrzędy przejścia. Systematyczne studium ceremonii, tłum. B. Biały, Państwowy Instytut Wydawniczy, Warszawa 2006.

32 Zob. T. Kowzan, dz. cyt., s. 171-172.

33 Zob. Motyw, w: Encyklopedia muzyki, red. A. Chodkowski, Państwowe Wydawnictwo Naukowe, Warszawa 1995, s. 578. 
Niekiedy są one dość proste, a nawet stereotypowe. Kalibanowi w Burzy towarzyszy nieregularny rytm bębnów (choć nie jest to typowe brzmienie na przykład afrykańskiego djembe), który ze szczególnym - wolniejszym, bardziej wysiłkowym - sposobem wymowy tej postaci $^{34}$ tworzy rodzaj wizytówki dzikiego i agresywnego stworzenia. W sposób nieco bardziej skomplikowany w tym samym spektaklu został muzycznie opisany Ferdynard ${ }^{35}$, któremu wtórują rozwibrowane syntezatorowe brzmienia.

W Poskromieniu złośnicy motywy muzyczne nie są ściśle przyporządkowane do konkretnych postaci, raczej sygnalizują pewne działania. I tak fanfarowy motyw bardzo często zapowiada pojawienie się jakiegoś bohatera, zadość czyniąc długiej tradycji w muzyce teatralnej i operowej, gdzie krótkie motywy w instrumentach dętych wieściły nadejście króla (bądź innej ważnej postaci). Tak zapowiedziani są na przykład Lucencjo i Bianka wracający z własnego ślubu.

Do funkcji sygnalizacyjnej można również zaliczyć muzyczne cytaty $^{36}$, które (w przeciwieństwie do muzyki autonomicznej) w muzyce scenicznej są zazwyczaj zaprezentowane bez znaczących modyfikacji w stosunku do oryginału. Tak dzieje się właśnie w przedstawieniach Warlikowskiego ${ }^{37}$. W (A)pollonii cytowana jest Berceuse Des-dur op. 57 Fryderyka Chopina. Jej delikatne, spokojne i niemal czułe brzmienie po raz pierwszy towarzyszy podskokom ubranej w sukienkę komunijną dziewczyny. Beztroska, zdawałoby się, zabawa, która wraz z muzyką Chopina tworzy spokojny, domowy obraz, okazuje się wstępem do pożegnania się Ifigenii (bo z ostatnich scen Ifigenii w Aulidzie Eurypidesa korzysta tutaj Warlikowski) z życiem i rodziną. Wraz z rozwojem akcji kołysanka milknie i zostaje zastąpiona krótko trwającymi współbrzmieniami o metalicznej barwie i niepokojącymi stukotami, które powoli zaczynają się zagęszczać. Scenę kończy kolejny cytat tym razem jest to tzw. tango samobójców, czyli przedwojenny szlagier To ostatnia niedziela z muzyką Jerzego Petersburskiego i tekstem Zenona Friedwalda. Utwór Chopina powraca jednak w tej insceni-

34 Wynika on z tego, że w rolę Kalibana wcieliła się austriacka aktorka Renate Jett.

35 W tej roli wystąpił Redbad Klynstra.

36 Na temat cytatu zob. Z. Lissa, O cytacie w muzyce, w: taż, Szkice z estetyki muzycznej, Polskie Wydawnictwo Muzyczne, Kraków 1965.

37 Korzystając z rozróżnienia Zofii Lissy, cytaty w muzyce do spektakli Warlikowskiego można zaliczyć do cytatów dosłownych, wydzielonych. Cytat ma być znakiem, który zostanie rozpoznany i odczytany przez odbiorców. Zob. tamże, s. 295. 
zacji wielokrotnie, stając się m.in. wstępem i zakończeniem jednej z piosenek -już nie cytatów, ale skomponowanych specjalnie na potrzeby spektaklu.

Z muzyką Fryderyka Chopina mamy również do czynienia w Krumie ${ }^{38}$. Nokturn Es-dur op. 9 nr 2 wybrzmiewa podczas dwóch wesel - Dupy z Tugatim oraz Trudy z Taktykiem. Swoją śpiewnością, słodyczą i pogodą wypełnia scenę całkowicie tych cech pozbawioną. Ale nokturn to również muzyka nocy - tego, co tajemne, być może wstydliwe i niechciane, a takimi są ślubne uroczystości bohaterów.

Cytat ukryty wewnątrz oryginalnego fragmentu muzycznego pojawia się natomiast w muzyce do spektaklu Anioły w Ameryce ${ }^{39}$. W melodii fortepianu jednego z quasi-jazzowych utworów mamy do czynienia z charakterystycznym motywem z Preludium e-moll op. 28 nr 4 Fryderyka Chopina. Ze względu na to, że Mykietyn korzysta tu jedynie z kilku dźwięków i osłania je, jak wyraziłby się Mieczysław Tomaszewski, „dymną zasłoną" ${ }^{0}$, chociażby za pomocą zmienionego instrumentarium i tonacji, powinniśmy w tym wypadku mówić raczej o aluzji ${ }^{41}$.

Wśród cytatów z twórczości innych kompozytorów wymienić należy fragment Wariacji Goldbergowskich (BWV 988) Johanna Sebastiana Bacha, które włączone zostają w akcję sceniczną (A)pollonii. Odtwarza je z dyktafonu współczesny Agamemnon ${ }^{42}$, który powraca z wojny.

38 Krum Hanocha Levina w przekładzie Jacka Poniedziałka, reżyseria: Krzysztof Warlikowski, scenografia: Małgorzata Szczęśniak, muzyka: Paweł Mykietyn, reżyseria światła: Felice Ross; premiera w Teatrze Rozmaitości 3.03.2005; wystąpili: Jacek Poniedziałek, Stanisława Celińska, Maja Ostaszewska, Małgorzata HajewskaKrzysztofik, Anna Radwan-Gancarczyk, Danuta Stenka, Redbad Klynstra, Marek Kalita, Zygmunt Malanowicz, Adam Nawojczyk, Paweł Kruszelnicki, Miron Hakenbeck.

39 Anioły w Ameryce na podstawie dramatu Tony'ego Kushnera w przekładzie Jacka Poniedziałka; reżyseria: Krzysztof Warlikowski, scenografia: Małgorzata Szczęśniak, muzyka: Paweł Mykietyn, światło: Felice Ross, film: Paweł Łoziński; premiera w Teatrze Rozmaitości 17.02.2007; wystąpili: Stanisława Celińska, Magdalena Cielecka, Maja Ostaszewska, Bogusława Schubert, Danuta Stenka, Andrzej Chyra, Rafał Maćkowiak, Zygmunt Malanowicz, Jacek Poniedziałek, Maciej Stuhr, Tomasz Tyndyk.

40 Zob. M. Tomaszewski, Muzyka Chopina na nowo odczytana, Akademia Muzyczna w Krakowie, Kraków 1996, s. 115.

41 Zob. B. Mika, Cytaty w muzyce polskiej XX wieku. Konteksty, fakty, interpretacje, Musica Iagellonica, Kraków 2008, s. 80-81.

$42 \mathrm{~W}$ tej roli wystąpił Maciej Stuhr. 
Wariacje włącza on sam, jako rodzaj potwierdzenia własnego wyznania, że tak naprawdę nie chciał być zbrodniarzem, ale pianistą. Towarzyszą one późniejszym słowom i działaniom Agamemnona, pozostając jedynie odległym echem, które swoim uporządkowanym pięknem przypomina o lepszej, lecz nigdy niezaistniałej wersji historii.

W Poskromieniu złośnicy natomiast na zasadzie cytatu przywołany zostaje utwór wokalno-instrumentalny - fragment arii Cavaradossiego Recondita armonia pochodzący z pierwszego aktu Toski Giacoma Pucciniego. Stanowi on rodzaj muzycznego opisu i wizytówki mężczyzny przedstawianego jako nauczyciel muzyki.

Charakterystyczną cechą pojawiających się w teatrze Warlikowskiego cytatów jest ich przynależność do żelaznego kanonu. Nie są to utwory rozpoznawalne wyłącznie przez melomanów, ich silne umocowanie w kulturze (również popularnej) sprawia, że funkcjonują na zasadzie znaku możliwego do odkodowania przez potencjalnego odbiorcę. Ważne jest również to, że znacząca ich większość przynależy do tzw. muzyki poważnej. Wśród cytatów z muzyki rozrywkowej można wymienić na przykład piosenkę To ostatnia niedziela oraz What a Wonderful World Louisa Armstronga czy fragment muzyki z filmu Dobry, zły i brzydki autorstwa Ennia Morricone. Nie oznacza to oczywiście, że ze stylistyki charakterystycznej dla muzyki popularnej Mykietyn nie korzysta. Podobnie jak w tworzonej przez siebie muzyce autonomicznej robi to bardzo często, jednak zamiast cytować, komponuje ją samodzielnie, jedynie zastosowanym brzmieniem, rytmiką czy instrumentarium nawiązując do danego gatunku ${ }^{43}$.

\section{Funkcja nadawania rytmu i tworzenia dynamiki przedstawienia}

O każdym scenicznym działaniu, które rozgrywa się w czasie, takim jak wypowiadanie tekstu, ruch, zmiany scenografii, wejścia i wyjścia postaci, można mówić w kategoriach związanych z tempem czy rytmem. Chociaż nie określa się ich z taką dokładnością, jak dzieje się to w utworach muzycznych, to jednak pozostają wyczuwalne i mają duży wpływ na całość przedstawienia. Bardzo często inscenizację trzyma w ryzach rytmicznych właśnie muzyka. W Poskromieniu złośnicy szybki, akor-

43 Warto zauważyć, że sam Mykietyn niechętnie włącza do muzyki scenicznej cytaty, zazwyczaj są to pomysły Warlikowskiego. Zob. K. Warlikowski, dz. cyt., s. 42. 
deonowy temat towarzyszy próbom zdobycia Bianki i Katarzyny oraz ślubnym pertraktacjom $\mathrm{z}$ ich ojcem. Jest on na tyle głośny, że aktorzy muszą go przekrzykiwać. Jednocześnie mocno wpływa na tempo podawania tekstu. Dynamiczność akcji idzie w parze z tempem muzyki, co oczywiście znajduje swoje odniesienie w treści sceny. Błyskawiczność zawieranych umów zbliża konkury do transakcji handlowych, nijak mających się do romantycznych uniesień.

O muzyce w Oczyszczonych można natomiast powiedzieć, że wymusza swoiste rallentando na innych komponentach przedstawienia. Długo wybrzmiewające syntezatorowe brzmienia spowalniają tempo i rozrzedzają rytmikę. Podobnie dzieje się w niektórych fragmentach Burzy, Hamleta ${ }^{44}$ czy Aniołów w Ameryce.

W (A)pollonii również pojawiają się sceny, których rytmikę zdaje się ustalać warstwa muzyczna. Oczywiste jest to przy rockowych piosenkach, które same prowokują do szybszego, ostrzejszego działania. Warte uwagi są jednak powtarzające się stukoty, trzaski i krótkie metaliczne brzmienia, które wypełniają przestrzeń sceniczną, gdy rozwój akcji danej „opowieści” zbliża się do kulminacji - tragicznego zakończenia. Prócz zmiany nastroju i atmosfery danej sceny (dźwięki te wprowadzają element grozy i niepokoju), wpływają również na tempo i dynamikę działań scenicznych, a także na sposób ich odbioru przez publiczność. Tutaj jednak zagęszczanie nie odbywa się równomiernie, dlatego nie mamy do czynienia ze stałym przyspieszeniem, ale raczej z ciągłym manipulowaniem percepcją rytmiki oraz czasu.

\section{Specyfika muzyki Mykietyna w teatrze Warlikowskiego}

Muzyka w teatrze Warlikowskiego nie jest jednorodna. Podobnie jak sam teatr, który posiadając charakterystyczny, rozpoznawalny ryt, przybiera różne kształty i odcienie w zależności od przedstawienia, tak i status oraz specyfika muzyki zmieniają się w zależności od pod-

44 Hamlet na podstawie dramatu Williama Shakespeare’a w przekładzie Stanisława Barańczaka, reżyseria: Krzysztof Warlikowski, przekład: Stanisław Barańczak, scenografia: Małgorzata Szczęśniak, muzyka: Paweł Mykietyn, choreografia: Saar Magal; premiera w Teatrze Rozmaitości 22.10.1999; wystąpili: Marek Kalita, Jacek Poniedziałek, Mirosław Zbrojewicz, Omar Sangare, Adam Woronowicz, Maria Seweryn, Jolanta Fraszyńska, Maria Maj, Cezary Kosiński, Robert Więckiewicz, Stanisława Celińska, Magdalena Cielecka. 
jętego tematu, tekstu czy formy inscenizacji ${ }^{45}$. Może ona pochodzić z widocznego źródła i być wykonywana na oczach widzów przez postać dramatyczną (jak ma to miejsce na przykład w Hamlecie, Krumie, Burzy, Elektrze ${ }^{46}$ ). Bywa, że została nagrana wcześniej i jest odtwarzana podczas spektaklu (tak dzieje się w Oczyszczonych, Krumie, Burzy) lub gra się ją na żywo, jednak z miejsca niewidocznego dla publiczności (jak w niektórych fragmentach Poskromienia złośnicy). Zdarza się również, że źródła emisji muzyki nie są ukryte i muzycy grają na scenie, nie wchodząc przy tym w rolę postaci. Wówczas silnie usamodzielniony fragment muzyczny przybiera funkcję koncertu (dzieje się tak w Poskromieniu złośnicy czy w (A)pollonii). W kontekście stosunku do uniwersum dramatycznego ${ }^{47}$ muzyka może zarówno stanowić część fikcji teatralnej, jak i istnieć poza nią, tworząc rodzaj tła. Zazwyczaj jednak spełnia te dwie role jednocześnie, a w obrębie jednego spektaklu piosenki postaci łączą się z muzyką odtwarzaną z niewidocznego źródła oraz wykonywaną na scenie.

Nietypowy dobór obsady wykonawczej, silne nawiązania do muzyki popularnej, rozwijanie materii dźwiękowej za pomocą narzędzi charakterystycznych dla minimal music oraz łączenie poszczególnych tematów i estetyk muzycznych na zasadzie kontrastu - to kilka cech wspólnych muzyki scenicznej tworzonej przez Pawła Mykietyna. W warstwie brzmieniowej szczególną uwagę zwraca dobór instrumentarium. Z instrumentów klasycznych sympatią darzy kompozytor instrumenty dęte drewniane (saksofon, klarnet), jak również fortepian i akordeon. Instrumenty smyczkowe wykorzystuje wyjątkowo rzadko - kwartet smyczkowy pojawia się chyba wyłącznie w Dybuku ${ }^{48}$. Instrumentem

45 Por. E. Kofin, Mistrz muzyki teatralnej, „Notatnik Teatralny” 72-73 (2013), s. 134-138. 46 Elektra na podstawie tragedii Sofoklesa w przekładzie Antoniego Libery i Janusza Szpotańskiego, reżyseria: Krzysztof Warlikowski, przekład: Antoni Libera, Janusz Szpotański, scenografia: Małgorzata Szczęśniak, muzyka: Paweł Mykietyn, choreografia: Wojciech Misiuro; premiera 18.01.1997 w Teatrze Dramatycznym w Warszawie; wystąpili: Danuta Stenka, Jadwiga Jankowska-Cieślak, Małgorzata Rudzka, Aleksandra Konieczna, Mariusz Bonaszewski, Sławomir Grzymkowski, Jolanta Olszewska, Grzegorz Wons, Zbigniew Bielski.

47 Z określeniem Patrice’a Pavisa „uniwersum dramatyczne” dyskutuje Magdalena Figzał. Zob. M. Figzał, Przestrzenie muzyczne w polskim teatrze wspótczesnym, Wydawnictwo Uniwersytetu Śląskiego, Katowice 2017, s. 100-108.

48 Dybuk na podstawie dramatu Dybuk Szymona An-skiego (przekład: Awiszaj Hadari) i noweli Hanny Krall pod tym samym tytułem; adaptacja i reżyseria: Krzysztof Warlikowski, scenografia: Małgorzata Szczęśniak, reżyseria świateł: 
zupełnie nietypowym, po który sięga Mykietyn dla nagrania warstwy dźwiękowej do Aniołów w Ameryce, jest obój chiński kupiony przez kompozytora na targu w Szanghaju (w spektaklu towarzyszy on monologowi Mai Ostaszewskiej). Wśród instrumentów przynależących do muzyki rozrywkowej warto natomiast wymienić gitarę elektryczną i basową, zestaw perkusyjny czy organy Hammonda.

Ważną cechą jest poszukiwanie nowego, nietypowego dla tych instrumentów rodzaju brzmienia. I tak na przykład saksofony imitują organy (w Poskromieniu złośnicy), fortepian prowadzi melodię jednogłosową (w Aniołach $w$ Ameryce), a kwartet smyczkowy tworzy wyłącznie akompaniament, który złożony jest z nieprzerywanych, dysonujących współbrzmień (w Dybuku). Co ciekawe, najczęściej wykorzystywane instrumenty należą do grupy tych, na których potrafi grać sam Mykietyn. Taki, a nie inny dobór wynika zatem również z kwestii praktycznych - kompozytor może z powodzeniem improwizować podczas prób, a później sam nagrać większość partii instrumentalnych.

Również brzmienia generowane cyfrowo (za pomocą syntezatora) stanowią ważną i obszerną część muzyki scenicznej Mykietyna. Zazwyczaj tworzą rodzaj plam dźwiękowych, na tle których rozbrzmiewa instrument solowy, wypowiedź lub śpiew aktora. Nie są one jednak stylistycznie jednorodne. Podczas gdy w Oczyszczonych są to proste, „siermiężne” brzmienia, o niemal niezmieniającej się dynamice (co przynosi skojarzenia z początkiem mody na tworzenie muzyki za pomocą syntezatora), tak na przykład w Burzy czy Krumie są one delikatniejsze, bardziej zróżnicowane, zespolone ze sobą za pomocą łagodnych, wysmakowanych zmian. Różnorodne pady i sample bardzo często przenikają się również z muzyką konkretną - zarejestrowaną wcześniej audiosferą parków, ulic, samolotu.

Za wspólny mianownik tego rodzaju działań należy uznać muzykę ambientową, którą jeden z jej prekursorów - Brian Eno - definiował jako muzykę otoczenia ${ }^{49}$. Jej głównym zadaniem jest budowanie nastroju, ale nie panowanie nad nim. Ma ona „wprowadzać spokój i tworzyć miejsce do myślenia”, jednocześnie „tak samo wciągać, jak i dawać

Felice Ross, muzyka: Paweł Mykietyn; prapremiera 6.10.2003 w Wytwórni Filmów Fabularnych we Wrocławiu; wystąpili: Magdalena Cielecka, Stanisława Celińska, Renate Jett, Irena Laskowska, Maria Łozińska, Orna Porat, Andrzej Chyra, Marek Kalita, Zygmunt Malanowicz, Jacek Poniedziałek, Jerzy Senator, Maciej Tomaszewski, Tomasz Tyndyk;

49 Zob. B. Eno, Ambient, tłum. J. Kutyła, w: Kultura dźwięku..., dz. cyt., s. 130. 
się ignorować" 50 . Od strony praktyki kompozytorskiej ambient wiąże się z operowaniem plamami dźwiękowymi, których następstwo odbywa się zazwyczaj w bardzo wolnym tempie i nie podlega linearnemu rozwojowi. Jawi się więc jako muzyka wyjątkowo statyczna, wchodząca $\mathrm{w}$ grę $\mathrm{z}$ odczuciem upływającego czasu. Jest to pewien wyznacznik teatralnej (i nie tylko) twórczości Pawła Mykietyna. Jak pisała o niej Ewa Szczecińska: „To nie jest muzyka akcji, to bardziej muzyka refleksji - kawałki, które komponowane do obrazu, same w sobie są powoli rozwijającym się kolażem swobodnie przepływających emocji" ${ }^{51}$.

Innym nurtem, do którego można przyporządkować muzykę teatralną Mykietyna, jest - blisko spokrewniony z ambientem - minimalizm $^{52}$. Większość fragmentów muzycznych cechuje prostota - są to zazwyczaj krótkie motywy melodyczne, oparte na „stojących” akordach. Podstawową zasadą techniki kompozytorskiej jest ich wielokrotne powtarzanie oraz bardzo powolne wprowadzanie zmian (harmonicznych, rytmicznych, melodycznych). Nie zawsze statyczność formy wiąże się tu z wolnym tempem - bardzo często wynika wyłącznie z ciągłego powtarzania krótkich motywów. Tak dzieje się na przykład w muzyce towarzyszącej dyskotekowej zabawie w przedstawieniu Krum. Opiera się ona na krótkim motywie, wykorzystującym prosty rytm i materiał dźwiękowy, który zostaje wielokrotnie powtórzony. Jedną z niewielu zmiennych jest w tym fragmencie muzycznym brzmienie. Mykietyn wykorzystuje bardzo różne sample, zmieniając je kilkukrotnie na przestrzeni jednego powtórzenia. Tworzy się w ten sposób komiczny efekt, jakby kompozytor na zasadzie przypadku łączył ze sobą poszczególne brzmienia. Muzyka pozostaje lekka, dominują wysokie rejestry i krótkie wartości rytmiczne, co w połączeniu z wyjątkowo dynamicznym tańcem bohaterów, potęguje karykaturalność sytuacji. Możemy również mówić o elementach mikrotonalności - na przykład w partii oboju chińskiego z Aniołów w Ameryce. Ruchliwa, przepełniona obiegnikami melodia rozlega się na tle akordów, które, w przeciwieństwie do niej, pozostają utrzymane w stroju równomiernie temperowanym.

50 Tamże.

51 Zob. E. Szczecińska, Mykietyn. Muzyka. Teatr, „Dwutygodnik.com”, https://www. dwutygodnik.com/artykul/3175-mykietyn-muzyka-teatr.html [dostęp: 15.10.2019].

$52 \mathrm{Na}$ temat podstawowych cech minimalizmu zob. J. Miklaszewska, Minimalizm w muzyce polskiej, Musica Iagellonica, Kraków 2003, s. 15-25. 
Takie połączenie stwarza wrażenie „nieczystości” i słuchowej niewygody wynikającej z nieprzystawalności obu systemów.

Przy porównaniu poszczególnych fragmentów zwraca uwagę również cechujący je wszystkie stylistyczny eklektyzm. Mykietyn zderza ze sobą różnorodne stylistyki o dość odległej proweniencji. I tak w Burzy fragmenty muzyczne stylizowane na renesansową chanson zostają zestawione z silnie zrytmizowaną współczesną muzyką taneczną, a pozbawione centrum tonalnego współbrzmienia o syntezatorowej barwie - z prostymi melodiami opartymi na akordach utrzymanych w systemie dur-moll. Owa mieszanina muzycznych estetyk jest również charakterystyczna dla kompozytorskiego idiomu Mykietyna, którego badacze chętnie określają jako postmodernistę ${ }^{53}$. Łączenie kontrastujących stylistyk czy brzmień odbywa się nie tylko w obrębie poszczególnych scen, ale również $\mathrm{w}$ ramach jednego fragmentu muzycznego. Nierzadko dwa całkiem odmienne plany muzyczne nakładają się na siebie, tworząc nowe jakości. Przykładem może być piosenka Ofelii z Hamleta, którą śpiewa Magdalena Cielecka. Rozpoczynają ją dwa akordy zawieszone, o przestrzennym, lekko rozwibrowanym brzmieniu syntezatora. Po kilku powtórzeniach zapanowuje nad nimi akompaniament akordeonowy, który dołącza wpierw w krótkich, urywanych motywach. Oba plany kontrastują ze sobą zarówno barwą, jak i harmonią. Jako głos trzeci pojawia się melodia piosenki, którą aktorka wykonuje nie do końca czysto, szorstką barwą głosu. Pod koniec utworu plany te zaczynają się chwiać - akordy w pierwszym z nich już nie stanowią równych wartości rytmicznych, akompaniament akordeonowy przyspiesza. Głosy nie mogą się odnaleźć, aż wreszcie utwór urywa się i milknie bez zakończenia. W takim ukształtowaniu utworu można odnaleźć pewne cechy początkowej twórczości autonomicznej Mykietyna, którego, jak sam mówi, „zawsze fascynowały [...] brudy, odpady, usterki" ${ }^{54}$.

Podobieństwa pomiędzy muzyką, jaką Mykietyn tworzy dla teatru, oraz jego autonomiczną twórczością to kwestia, która w niniejszym artykule może być jedynie zasygnalizowana. Przenikanie się tych dwóch rodzajów aktywności można zauważyć zarówno na poziomie konkretnych fragmentów muzycznych, które kompozytor zapożyczył

53 Zob. A. Kwiecińska, W co gra Paweł Mykietyn?, „Ruch Muzyczny” 2007, nr 10, s. 7.

54 Zob. E. Olejnik, Mykietyna inspiracje fonografia, „Notatnik Teatralny” 72-73 (2013), s. 152. 
z muzyki teatralnej (na przykład fragment z Dybuka został wykorzystany w utworze Kartka $z$ albumu na wiolonczelę i taśmę, a fragment z Elektry - w Pasji według św. Marka) ${ }^{55}$, jak i podobieństwa na obszarze kompozytorskich chwytów. Muzyka rockowa silnie dominująca w (A)pollonii stanowiła ważny element we wspomnianej już Pasji według św. Marka, syntezatorowe plamy dźwiękowe z Oczyszczonych kojarzą się z rozpoczęciem Epifory na taśmę, której urwanemu zakończeniu znowuż blisko do piosenki Ofelii z Hamleta. To przenikanie się kompozytorskich inspiracji świadczy w mojej ocenie o równorzędności w traktowaniu przez Pawła Mykietyna obu nurtów swojej twórczości ${ }^{56}$.

Omówione przykłady pokazują, że muzyka w teatrze Warlikowskiego przyjmować może różnorodne role. Bywa komentarzem, nierzadko ironicznym, wobec słowa czy gestykulacji aktorów. Na zasadzie kontrapunktu wchodzi z innymi komponentami teatru w pełną napięcia, wielopoziomową grę, dekonstruując pozorne znaczenie poszczególnych scen. Dopełnia scenografię, gdy jako dźwiękowa dekoracja dookreśla miejsce akcji, a także porządkuje formę przedstawienia za pomocą łączników czy motywów przewodnich. Niekiedy jest nawet „intensywniejsza niż tekst, niż gest teatralny, z którymi dopiero wspólnie, przez wzajemne dopełnianie, tworzy sugestywny, nieledwie szamański rytuał" ${ }^{7}$. Nie będzie chyba przesadnym stwierdzenie, że teatr Krzysztofa Warlikowskiego przybrałby zupełnie inny kształt, gdyby nie muzyka Pawła Mykietyna - integralna, choć często niezauważana część tego wciąż rozwijającego się fenomenu.

55 Zob. P. Mykietyn, Teatr Mykietyna na płycie, rozmowę przepr. A.S. Dębowska, "Gazeta Wyborcza - Stołeczna” 2012, nr 30; http://www.e-teatr.pl/pl/artykuly /132384,druk.html [dostęp: 15.10.2019].

$56 \mathrm{Na}$ ten temat Paweł Mykietyn wypowiadał się zresztą w licznych wywiadach. Zob. P. Mykietyn, Kompozytor muzyki teatralnej? Nie ma kogoś takiego, rozmowę przepr. Ł. Orłowski, „Teatr” $2008 \mathrm{nr}$ 9, http://encyklopediateatru.pl/artykuly/61132/kompozytor-muzyki-teatralnej-nie-ma-kogos-takiego [dostęp: 15.10.2019]; P. Mykietyn, Należę do pokolenia, rozmowę przepr. M. Ruszpel, „Notatnik Teatralny" 16-17 (1998); P. Mykietyn, Wspóltworzymy czasy, rozmowę przepr. A. Korytkowska, „Notatnik Teatralny” 28-29 (2003).

57 Zob. D. Kozińska, Szaman Warlikowskiego, „Teatr” 2013, nr 4, http://www.teatr-pismo.pl/ludzie/477/szaman_warlikowskiego/ [dostęp: 15.10.2019]. 


\section{Bibliografia}

Balcerzan E., Osiński Z., Spektakl teatralny w świetle teorii informacji, w: Wprowadzenie do nauki o teatrze, t. 1, Dramat, teatr, red. J. Degler, Uniwersytet Wrocławski im. Bolesława Bieruta, Wrocław 1974.

Capeau J., Naga scena, tłum. M. Skibniewska, Wydawnictwa Artystyczne i Filmowe, Warszawa 1972.

Eno B., Ambient, tłum. J. Kutyła, w: Kultura dźwięku. Teksty o muzyce nowoczesnej, red. Ch. Cox i D. Warner, słowo/obraz terytoria, Gdańsk 2010.

Figzał M., Przestrzenie muzyczne w polskim teatrze współczesnym, Wydawnictwo Uniwersytetu Śląskiego, Katowice 2017.

Gennep A. van, Obrzędy przejścia. Systematyczne studium ceremonii, tłum. B. Biały, Państwowy Instytut Wydawniczy, Warszawa 2006.

Hausbrandt A., Elementy wiedzy o teatrze, Wydawnictwa Szkolne i Pedagogiczne, Warszawa 1981.

Kane S., Oczyszczeni, tłum. A. Kaszowska, https://docer.pl/doc/1ose8 [dostęp: 14.10.2019].

Kofin E., Mistrz muzyki teatralnej, „Notatnik Teatralny” 72-73 (2013).

Kowzan T., Znak w teatrze, „Dialog” 1969, nr 3.

Kozińska D., Szaman Warlikowskiego, „Teatr” 2013, nr 4, http://www. teatr-pismo.pl/ludzie/477/szaman_warlikowskiego/ [dostęp: 15.10.2019].

Kwiecińska A., W co gra Paweł Mykietyn?, „Ruch Muzyczny” 2007, nr 10.

Lehmann H.T., Teatr postdramatyczny, tłum. D. Sajewska, M. Sugiera, Księgarnia Akademicka, Kraków 2004.

Lissa Z., Szkice z estetyki muzycznej, Polskie Wydawnictwo Muzyczne, Kraków 1965.

Mika B., Cytaty w muzyce polskiej XX wieku. Konteksty, fakty, interpretacje, Musica Iagellonica, Kraków 2008.

Miklaszewska J., Minimalizm w muzyce polskiej, Musica Iagellonica, Kraków 2003.

Motyw, w: Encyklopedia muzyki, red. A. Chodkowski, Państwowe Wydawnictwo Naukowe, Warszawa 1995.

Mykietyn P., Kompozytor muzyki teatralnej? Nie ma kogoś takiego, rozmowę przepr. Ł. Orłowski, „Teatr” $2008 \mathrm{nr}$ 9, http://encyklo- 
pediateatru.pl/artykuly/61132/kompozytor-muzyki-teatralnej-niema-kogos-takiego [dostęp: 15.10.2019]

Mykietyn P., Należę do pokolenia, rozmowę przepr. M. Ruszpel, „Notatnik Teatralny” 16-17 (1998).

Mykietyn P., Wspóttworzymy czasy, rozmowę przepr. A. Korytkowska, „Notatnik Teatralny” 28-29 (2003).

Olejnik E., Mykietyna inspiracje fonografia, „Notatnik Teatralny” 72-73 (2013).

Pavis P., Słownik terminów teatralnych, tłum. S. Świontek, Zakład Narodowy im. Ossolińskich, Wrocław 1998.

Schaeffer P., Akuzmatyka, tłum. J. Kutyła, w: Kultura dźwięku. Teksty o muzyce nowoczesnej, red. Ch. Cox i D. Warner, słowo/obraz terytoria, Gdańsk 2010.

Szczecińska E., Mykietyn. Muzyka. Teatr, „Dwutygodnik.com”, https:// www.dwutygodnik.com/artykul/3175-mykietyn-muzyka-teatr.html [dostęp: 15.10.2019].

Szulc T., Muzyka i teatr, w: Wprowadzenie do nauki o teatrze, red. J. Degler, t. 2, O tworzywie i twórcach dzieła teatralnego, red. J. Degler, Wydawnictwa Uniwersytetu Wrocławskiego, Wrocław 1976.

Tomaszewski M., Muzyka Chopina na nowo odczytana, Akademia Muzyczna w Krakowie, Kraków 1996.

Warlikowski K., Muzyka, która wchodzi w kości, rozmowę przepr. P. Dobrowolski, „Notatnik Teatralny” 72-73 (2013)

Wroński W., Muzyka w dramacie, tragedii i komedii, w: Wprowadzenie do nauki o teatrze, t. 2, O tworzywie i twórcach dzieła teatralnego, red. J. Degler, Wydawnictwa Uniwersytetu Wrocławskiego, Wrocław 1976. 